\title{
MAKING EVERY FERTILIZER DOLLAR PAY
}

\author{
John E. Sawyer \\ Associate Professor and Extension Soil Fertility Specialist \\ Department of Agronomy \\ Iowa State University
}

In an ideal crop production system, all nutrient and limestone needs would be determined by evaluating expected return from each input, without required purchases being limited by overall financial resources. More realistically, resources get allocated by priority need, and decisions related to fertilizer and limestone use are judged against other crop production needs, enterprise requirements, and overall farm business goals. This allocation becomes especially pertinent when cash flow is low and financial resources become inadequate. In this situation, and considering all potential inputs, the focus should be on garnering the greatest return to each input dollar expended. Prioritizing fertilizer and lime use should be to those areas that will produce the greatest profit. Following is information to help guide fertilization and liming decisions when funds are simply not available to pay for all desired inputs -- keeping in mind that the goal is on ensuring adequate crop production by addressing critical crop input needs, while at the same time attempting to minimize negative impacts from potentially less than optimal production.

\section{Soil Test Information}

Decisions regarding fertilization and liming are based on information derived from soil test results. Without this information it is not possible to make informed decisions regarding lime or nutrient applications. When finances are limited, using soil tests is the best approach to ensure most successful use of dollars spent on fertilizers and limestone.

If soil testing is a traditional component of crop management, then soil test results, along with past nutrient and limestone use, will be available to assist in resource allocation decisions. If current soil tests are not available, or worse yet there are none, then some money should be spent determining this information - it is the only way to understand the potential need for fertilization and liming. For fields with sub-field or intense soil test information, then directing nutrient or lime applications only to deficient testing areas can aid in reducing overall input costs. Also, documented records and information on the productivity of soils, fields, or field areas help derive nutrient recommendations that fit reasonable expectations of crop yield.

\section{Liming}

Increasing the $\mathrm{pH}$ of acid soils to a range optimal for crop production is the long-term goal of liming programs, and once achieved provides a cushion for many years of high yields without the need for frequent application. Maintaining $\mathrm{pH}$ in this range also increases the plant availability of many crop nutrients. Recommendations from Iowa State University suggest applying limestone if soil $\mathrm{pH}$ falls below 6.0 for straight grass pastures or grass hay, below 6.4 for corn and soybean (below 6.0 on soils with high $\mathrm{pH}$ subsoils), and below 6.8 for alfalfa - with the expectation of raising $\mathrm{pH}$ to 6.5 for straight grass pastures, grass hay, corn, and soybean and to 6.9 for alfalfa production (Voss et al., 1999).

In situations of limited financial resources, some adjustment in the soil $\mathrm{pH}$ level to trigger lime application is appropriate. The application strategies outlined below will help with lime allocation on the short term. However, similar questions will arise as fields by-passed this year are rotated next year. Limestone applications correct soil $\mathrm{pH}$ for several years, therefore applications inherently provide $\mathrm{pH}$

Presented at the $11^{\text {th }}$ annual Integrated Crop Nutrient Management Conference, p. 63-78. Dec. 12, 1999. Iowa State University, Ames, IA. 
correction for several crops and costs can be amortized over time. However, this long-term benefit does not help a short-term financial situation.

High priority application: apply lime to fields or field areas that test less than 5.5, no matter what crop will be grown. Although this application may be costly because of the large limestone need, consider applying enough limestone to raise $\mathrm{pH}$ to 6.5 for row crops and grass forages ( 6.0 for grass pastures and grass haylands), and to 6.9 for alfalfa. Of the crops mentioned, alfalfa is the most sensitive to low $\mathrm{pH}$, and considering the high establishment cost and need for stand longevity, it should have priority for lime application. For the corn-soybean rotation, soybean is more sensitive to low $\mathrm{pH}$ than corn and should receive priority liming. Because of the time required for limestone to react and raise $\mathrm{pH}$, and the fact that soybean is rotated with corn, strategies that target application before soybean instead of corn do have limited appeal. It is probably better to consider the rotation rather than an individual crop. In consideration of total limestone cost, the amount of material applied in any one application may be reduced, but remember the target $\mathrm{pH}$ and full yield benefit will not be achieved until the total amount is applied.

Desirable application: if soil $\mathrm{pH}$ is between 5.5 and 6.0, apply lime, especially for the most sensitive crops like alfalfa and soybean. In a study conducted on Galva-Marcus-Primghar soil complex (0-6 inch soil $\mathrm{pH}$ of 5.6) soybean yield increased with lime application, but corn did not (Table 1). Studies at several sites across Iowa, Tables 2 and 3, showed limited soybean and corn yield increase to lime application when soil $\mathrm{pH}$ was less than 6.0, but no soybean or corn yield response when $\mathrm{pH}$ was 6.0 or above. Small and inconsistent response to lime application when soil $\mathrm{pH}$ is below 6.0 has been observed in several long-term rate studies (Tables 4-8). Combined, these studies indicate that if lime is withheld on soils testing in the 5.5 to 6.0 range, soybean and corn yield can be depressed, but often not dramatically. An alternative approach would be to only apply enough lime to raise $\mathrm{pH}$ to 6.0 instead of to 6.5.

Optional application: if soil pH is 6.0 to 6.4 then limestone application is optional for corn and soybean and not needed for straight grass pastures or grass hay. Priority should be before establishing alfalfa. If finances are not a consideration, costs for maintaining soil $\mathrm{pH}$ at 6.5 should be no more than for maintaining $\mathrm{pH}$ at 6.0.

\section{Nitrogen}

Crops like corn, wheat, oat, and grasses are quite responsive to $\mathrm{N}$ supply and thus $\mathrm{N}$ management is critical for profitable production. High priority should be focused on determining the amount of $\mathrm{N}$ required, and finding resources to purchase and make needed applications.

Also of prime importance is adjusting total $\mathrm{N}$ application rates, and thus reducing costs, by accounting for and utilizing $\mathrm{N}$ available from various sources -- due to rotation following alfalfa and soybean, from manure, from various byproducts, and from secondary fertilizers like, weed-and-feed, starter, and ammoniated phosphates. These sources can supply significant amounts of crop available $\mathrm{N}$, and if properly accounted for and managed will greatly lower overall fertilizer $\mathrm{N}$ needs and costs.

One example of the rotation benefit is corn following alfalfa. Research by Morris et al. (1993) in Iowa found virtually no $\mathrm{N}$ fertilization need for first-year corn after alfalfa (three of 29 sites had positive net return from application of $50 \mathrm{lb}$ N/acre, the rest did not respond to applied $\mathrm{N}$ ). Table 9 shows the low number of responsive sites and low optimum $\mathrm{N}$ need for first year corn after forage legume measured in studies from several states. Response to $\mathrm{N}$ is greater and more variable for second-year corn after alfalfa, but still less than for continuous corn (studies by Blackmer et al. (1992) found 16 of 24 sites did not respond to applied $\mathrm{N}$, but the other eight had economic optimum rates above $100 \mathrm{lb} \mathrm{N} / \mathrm{acre}$ ). Another example of the rotation benefit is the increase in corn yield and lower $\mathrm{N}$ requirement when corn is grown 
after soybean compared to corn following corn. Table 10 shows the yield benefit of soybean-corn rotation compared to continuous corn from several studies. Concurrent to the increased yield with soybean-corn rotations is the lower $\mathrm{N}$ requirement of corn when grown after soybean (Table 11 gives the apparent nitrogen contribution from soybean to corn measured in several studies). Tables 12 and 13 show the effect of long-term rotation on both corn $\mathrm{N}$ need and crop yields at two sites in Iowa. Current suggestions are to account for up to $50 \mathrm{lb}$ N/acre less $\mathrm{N}$ need for corn following soybean than for continuous corn.

Choice of $\mathrm{N}$ rate can impact both economic return and residual inorganic-N remaining in the soil. Application at rates greater than corn need is a major reason for excess nitrate found in corn cropping systems. Although optimal fertilization rates do vary between years, using the highest-ever yield produced to set $\mathrm{N}$ rates will result in over-application and lower economic return in many years and in the long-term. It is more appropriate to set rates on longer-term proven productivity rather than the infrequent high-yielding year or short-term period. In a long-term rotation study in Illinois (Table 14), both the range in yearly plateau $\mathrm{N}$ rate and the highest plateau $\mathrm{N}$ rate was greatest for the lower yielding years. The highest yielding years did not require the highest $\mathrm{N}$ rates. Choosing a rate based on proven yields from several seasons will not limit production in the high yielding years because the soil typically supplies more $\mathrm{N}$ in those years and corn is more efficient in utilizing fertilizer $\mathrm{N}$. The combination of good growing weather, and improved $\mathrm{N}$ supply and uptake, results in higher yield without the requirement for higher $\mathrm{N}$ application. In times of tight finances, it would seem most appropriate to set rates that are realistic for the longer-term proven productivity. For a corn-soybean rotation, selecting rates that fall within an approximate 100 to $150 \mathrm{lb}$ N/acre range, and following good N management strategies, should afford economic corn production, without limiting yield. As an example, it would require a corn productivity above $170 \mathrm{bu} / \mathrm{acre}$ to result in a base $\mathrm{N}$ recommendation above $150 \mathrm{lb}$ N/acre (using $1.2 \mathrm{lb} \mathrm{N} / \mathrm{bu}$ minus $50 \mathrm{lb} \mathrm{N} / \mathrm{acre}$ for the rotation effect).

Crop price and $\mathrm{N}$ cost both influence economic optimal $\mathrm{N}$ rates, with higher optimal rates when $\mathrm{N}$ cost is low and crop price is high, and conversely, lower rates when $\mathrm{N}$ cost is high and crop price is low (examples in Blackmer et al., 1992; Blackmer, 1996). Within a corn price range from $\$ 3.00$ to $\$ 1.50 / \mathrm{bu}$, the reduction in optimum $\mathrm{N}$ rate is not large unless $\mathrm{N}$ costs are high. One should carefully consider the prices used in these evaluations - the price now may not be what it is in the future or at harvest next fall.

Of particular interest is the response to applied $\mathrm{N}$ that might occur in specific field situations. Use of $\mathrm{N}$ diagnostic tools can help guide field specific decisions and assist with determination of economical $\mathrm{N}$ use. For instance, the late spring soil nitrate test can aid in determining soil/manure $\mathrm{N}$ supply in previously manured fields.

Manure is an excellent source of crop available N. Recent data collected in Iowa shows both high corn yield and high $\mathrm{N}$ availability from swine manure application (Table 15). In that study, corn yields with applied manure were higher than with fertilizer $\mathrm{N}$ alone. In studies conducted on multiple sites across Iowa on manured soils (most sites had manure applied for the corn crop, but some sites had no manure applied since harvest of the previous crop but did receive manure at least 2 of the last 4 years), many sites did not respond to applied fertilizer $\mathrm{N}$, or response was limited to low rates (Table 16). In a multi-site study utilizing liquid dairy and swine manure, University of Minnesota researchers found acceptable corn production with October and April manure application compared to spring fertilizer $\mathrm{N}$ (fall manure application averaged about 5\% less than manure applied in spring, Table 17). Appropriately utilizing manure $\mathrm{N}$ is another opportunity to lower fertilizer $\mathrm{N}$ needs.

Risk of $\mathrm{N}$ loss becomes an important issue when refining rates to optimal or perhaps less than optimal if financial resources limit the amount of $\mathrm{N}$ that can be purchased relative to the total need. Spring preplant application close to planting or sidedress typically provides the least risk from loss - although if weather 
and soil conditions are favorable, late fall application can be comparable but risk and probability of loss increases because of the increased time the applied $\mathrm{N}$ is exposed to the environment. If fall applications must be made, they should be targeted to soils and geographic areas with lowest loss potential, and application should not occur until soils have cooled sufficiently to slow nitrification (temperature at the 4inch soil depth $50^{\circ} \mathrm{F}$ and expectation is for continued cooling).

\section{Phosphorus and Potassium}

Highest priority for $\mathrm{P}$ and $\mathrm{K}$ applications should be to fields or field areas with soil tests in the very low and low categories - soil tests below the optimum range where yield increase will provide greatest return to the fertilizer investment (Mallarino et al., 1991; Webb et al., 1992; Mallarino and Blackmer, 1995; Voss et al., 1999). If adequate fertilizer cannot be applied in these situations, then reduced yield and profitability will occur. If manure is available, then application should be targeted to these fields. With the advent of intense soil sampling, and the ability to selectively apply fertilizers and manure within fields, there is opportunity to make applications only to the deficient testing areas, and avoiding those that do not need additional nutrients.

It would be desirable to apply $\mathrm{P}$ and $\mathrm{K}$ to soils testing optimum as yield increase is expected at those soil test levels. However, yield increase and return to the fertilizer cost is not as frequent or as large as with lower soil tests. For the long-term it may be profitable to maintain soil tests in the optimum range, but in times of tight finances, those applications could be reduced but should not be eliminated unless necessary.

On the short term, P and K can be withheld on soils testing slightly above optimum (Voss et al., 1999), however realizing that with crop harvest and resultant removal of nutrients soil tests will decline and increased fertilization will eventually be required. Application at this test level is optional. If a build-up and maintenance approach to $\mathrm{P}$ and $\mathrm{K}$ fertility management has been followed, then once soil tests are built up, fertilizer application can be withheld during tight economic times with no detrimental impact on crop production (which is one goal of that program). Soils testing high and very high have little probability of yield increase from nutrient application, and could have $\mathrm{P}$ and $\mathrm{K}$ withheld for several years before fertilization would be required. Application is not needed, and considering environmental $\mathrm{P}$ issues, $\mathrm{P}$ application should be avoided on very high testing soils. Soils should be tested to monitor changes in test levels if fertilization is withheld.

The number of years fertilizer is withheld until a yield decline is observed is dependent upon the beginning soil test level. When soil tests are already deficient, yield loss will occur in the first year, but when soil tests are high to very high, there will be several years before soil tests decrease to responsive levels and a yield loss would be observed (examples from long-term studies in Tables 18 and 19). The length of this time period increases as the initial soil test level increases above the optimum. For instance, as shown in Table 18, at a soil P test of $17 \mathrm{ppm}$, three crops were grown before the fourth crop showed a response to applied P. But at a soil P test of $43 \mathrm{ppm}$, nine crops were grown before the tenth crop showed a response to applied P. Similar results would be expected for K (Table 19). Also, as the soil test becomes more deficient, the yield increase from $\mathrm{P}$ or $\mathrm{K}$ application grows larger, or conversely, if $\mathrm{P}$ or $\mathrm{K}$ is withheld the yield loss becomes larger (Tables 18 and 19).

The rate of soil test decrease when $\mathrm{P}$ or $\mathrm{K}$ fertilizer is withheld appears to depend upon the beginning soil test level (examples from long-term studies in Tables 18-22), prior rate and time period of nutrient application, and yield (crop removal rate). For instance, at a beginning soil test level of $17 \mathrm{ppm}$, after four crop years soil test $\mathrm{P}$ had declined to $9 \mathrm{ppm}$, a decrease of $8 \mathrm{ppm}$ (Table 20). After another four crop years soil test $P$ declined further to $6 \mathrm{ppm}$ (a change of $3 \mathrm{ppm}$ ). And for another four crop years soil test $\mathrm{P}$ did not decline further, it remained at $6 \mathrm{ppm}$. From these studies, it appears that the higher the soil test level, the greater the decline - especially in situations where soil tests were increased by a large nutrient 
application (likely a combination of soil processing and crop removal). As shown in Tables 18-22, when tests have moderated for a few years after the initial fertilizer application, the rate of decrease is smaller and tests are more stable. If soil tests have been maintained at a high level for a number of years, the rate of decrease would likely not be as rapid as found shortly after a one-time large P or K application. Also, as soil tests approach very low levels, an equilibrium occurs between crop removal, re-cycling of $\mathrm{P}$ and $\mathrm{K}$ from crop residues, and soil chemical reactions that supply available $\mathrm{P}$ and $\mathrm{K}$ - thus soil tests only slowly decline or reach roughly a stable test level. For P, soil fixation of applied P appeared to be only a small factor in regard to recovering applied fertilizer $\mathrm{P}$ in these studies. In the long-term $\mathrm{P}$ study at Kanawha (Table 18), with a one-time application of $300 \mathrm{lb}_{2} \mathrm{O}_{5}$, the soil test $\mathrm{P}$ returned to the original $17 \mathrm{ppm}$ level after crop removal of roughly the same amount as initially applied (seven years of soybean and corn crop removal at the yields measured in the study). The same occurred for the higher $600 \mathrm{lb}$ rate, the only difference being it took 13 years of crop removal at the yields measured in the study to reach the original soil test $\mathrm{P}$ level (Table 18). For $\mathrm{K}$, the recovery of applied $\mathrm{K}$ appears more influenced by the soil than for $\mathrm{P}$. With application of 300 or $600 \mathrm{lb} \mathrm{K}_{2} \mathrm{O}$ (Kanawha and Boone sites), initially soil tests declined rapidly, and once soil tests returned to original levels (56 ppm at the Kanawha site and $71 \mathrm{ppm}$ at the Boone site, Tables 19, 21, and 22) not as much $\mathrm{K}$ had been removed by the corn and soybean crops as had been applied. Therefore some K added remained in the soil or soil-plant system and was not measured by the soil test.

Starter should be applied for corn if soil or environmental conditions frequently result in response to that application. If reduction in recommended broadcast $\mathrm{P}$ and $\mathrm{K}$ rates is necessary, then consider two by two starter or banding which will enhance efficiency and lower fertilizer costs.

Also, credit $\mathrm{P}$ and $\mathrm{K}$ from manure application. Most manure contains significant amounts of crop available $\mathrm{P}$ and $\mathrm{K}$, and in many instances can supply the $\mathrm{P}$ and $\mathrm{K}$ needs of more than one crop.

\section{Secondary and Micronutrients}

Secondary and micronutrient deficiencies can have an impact on productivity if deficient. However, their application should only be considered for confirmed deficiency symptoms or documented yield responses - situations usually tied to special soil and climatic conditions. Blanket or shotgun application, especially when considering maximizing tight financial resources, is not the best approach for applying secondary or micronutrient products. Rather, targeted applications should only be made for specific deficient situations and application requirements. In Iowa most soils supply adequate amounts of these nutrients and likelihood of yield enhancement is relatively low, especially compared to that frequently observed for nitrogen, phosphorus, and potassium.

Zinc supply can be deficient for corn, especially on calcareous soils. Consider Zn application if the soil test is low (DTPA test less than $0.5 \mathrm{ppm}$ ). Zinc fertilization rates and costs can be reduced significantly when $\mathrm{Zn}$ is banded compared to broadcast applied. Iron deficiency in soybean sometimes occurs on calcareous soils. Use of tolerant soybean varieties is generally the accepted and least cost solution to this deficiency, rather than iron application.

\section{Ways to Maintain and Even Improve Crop Yields While Saving on Nutrient Costs}

- Rotate crops to achieve higher yields and lower $\mathrm{N}$ needs

- Account for rotation $\mathrm{N}$ benefits when planting crops after soybean, alfalfa, or other legumes

- Soil test

- Use and account for manure nutrient sources

- Time $\mathrm{N}$ fertilizer and manure application appropriately for most efficient crop use 
- Account for all intended fertilizer $\mathrm{N}$ applications - like weed and feed, starter, and ammoniated phosphates before setting the rate for, and making the primary $\mathrm{N}$ fertilizer or manure application

- Accurately apply fertilizer and manure

- Band instead of broadcasting P and $\mathrm{K}$

- Investigate use of diagnostic tools like soil nitrate testing, fall cornstalk nitrate testing, leaf chlorophyll readings, aerial images, and green leaf ratings to help assess corn $\mathrm{N}$ programs

- Manage crop production practices such as plant populations, hybrid/varieties, and pest management to ensure high yields

- Be realistic when setting yield expectations - use proven yields, not unrealistic goals

\section{Summary}

Tight cash flow and limited financial resources adds to the challenge of achieving most profitable crop production. This is especially difficult for management of nutrient and limestone inputs because their cost can be a substantial part of all needed production inputs and returns from these inputs often accrue over multiple years, so total profits cannot be recovered immediately. With careful attention to the nutrient areas affording greatest potential return, limited fertilizer dollars can be targeted to priority situations critical for producing a crop. Some key applications are: $\mathrm{N}$ for corn, wheat, oat, and grass crops; P and K to low and very low testing soils; lime to rotations that include alfalfa, and lime when soil $\mathrm{pH}$ is less than 5.5. The overall result may not fit long-range plans, but can provide acceptable profitability for the short-term. When the financial situation improves, then attention can again be focused on areas that, by necessity, were not addressed during the current time period.

\section{References}

Blackmer, A.M., T.F. Morris, and B.G. Meese. 1992. Estimating nitrogen fertilizer needs for corn at various management levels. p. 121-134. In Proceedings of the forty-seventh annual corn and sorghum industry research conference. American Seed Trade Assoc., Washington, D.C.

Blackmer, A.M. 1996. How much nitrogen do soybeans leave for corn? p. 49-53. In Proceedings of the eight annual integrated crop management conference. Iowa State University, Ames, IA.

Bundy, L.G. 1998. Soybean nitrogen contributions and rotation effects. p. 27-36. In Vol. 14, Proceedings of the North Central Extension-Industry Soil Fertility Conference. Nov. 11-12. St. Louis, MO.

Hansen, D.J., A.M. Blackmer, and A.P. Mallarino. 1998. Optimizing nitrogen management in manured cornfields. p. 121-126. In Vol. 14, Proceedings of the North Central Extension-Industry Soil Fertility Conference. Nov. 11-12. St. Louis, MO.

Kassel, P., J.E. Sawyer, D. Haden, and S. Parker. 1999. Soil pH and corn-soybean rotation yield responses to limestone application and tillage. p. 260. In Agronomy Abstracts, Am. Soc. Agronomy, Madison, WI.

Killorn, R. 1998. Frequency of liquid swine manure application. p. 34-36. In ISRF98-22, Iowa State University Northern Research and Demonstration Farm Annual Progress Report, Ames, IA.

Mallarino, A.P., J.R. Webb, and A.M. Blackmer. 1991. Soil test values and grain yields during 14 years of potassium fertilization of corn and soybean. J. Prod. Agric. 4:562-566. 
Mallarino, A.P., and A.M. Blackmer. 1995. Phosphorus and potassium fertilization of corn and soybean. p. 2.30-2.35. In Report of integrated farm management. IFM 16. Iowa State University, Ames, IA.

Mallarino, A.P., and K. Pecinovsky. 1998. Effects of crop rotation and nitrogen fertilization on crop production over a 20-year period. p. 13-16. In ISRF98-13, Iowa State University Northeast Research and Demonstration Farm Annual Progress Report, Ames, IA.

Mallarino, A.P., and D. Rueber. 1998. Crop rotation and nitrogen fertilization for crop production. p. 30-33. In ISRF98-22, Iowa State University Northern Research and Demonstration Farm Annual Progress Report, Ames, IA.

Morris, T.F., A.M. Blackmer, and N.M. El-Hout. 1993. Optimal rates of nitrogen fertilization for firstyear corn after alfalfa. J. Prod. Agric. 6:344-350.

Randall, G.W., M.A. Schmitt, and J.P. Schmidt. 1999. Corn production as affected by time and rate of manure application and nitrapyrin. J. Prod. Agic. 12:317-323.

Voss, R.D., J.E. Sawyer, A.P. Mallarino, and R. Killorn. 1999. General guide for crop nutrient recommendations in Iowa. Publication Pm-1688 (rev.). Iowa State University, Ames, IA.

Webb, J.R., A.P. Mallarino, and A.M. Blackmer. 1992. Effects of residual and annually applied phosphorus on soil test values and yields of corn and soybean. J. Prod. Agric. 5:148-152. 
Table 1. Effect of ag-ground limestone application rate on soybean and corn grain yield for 5-years after application, Iowa State University Northwest Research Farm, 1999. Limestone applied December 1993 to no-till, ridge-till, and chisel plow systems (Galva-Marcus-Primghar soils with 30 to 50 inch depth to carbonates). Kassel et al., 1999.

Effect of Aglime Rate on Soybean Yield, ISU Northwest Research Farm

\begin{tabular}{|c|c|c|c|c|c|c|}
\hline \multirow[b]{2}{*}{ Aglime } & \multicolumn{5}{|c|}{ Year } & \multirow[b]{2}{*}{ Mean } \\
\hline & 1994 & 1995 & 1996 & 1997 & 1998 & \\
\hline lb ECCE/acre & \multicolumn{6}{|c|}{ - - - - - - - - - - - - bu/acre - - - - - - - - - - - - } \\
\hline 0 & 35.2 & 42.1 & 45.7 & 49.6 & 44.7 & 43.4 \\
\hline 500 & 35.5 & 44.6 & 44.7 & 50.2 & 44.9 & 44.0 \\
\hline 1000 & 38.1 & 45.8 & 47.1 & 54.5 & 46.5 & 46.4 \\
\hline 2000 & 38.2 & 46.3 & 47.2 & 54.1 & 47.0 & 46.6 \\
\hline 4000 & 37.7 & 46.8 & 47.6 & 57.9 & 46.7 & 47.3 \\
\hline 6000 & 38.7 & 46.6 & 49.8 & 57.2 & 48.4 & 48.2 \\
\hline Significance & $\star \star \star ~$ & $\star \star \star$ & $\star \star \star$ & $\star \star \star$ & $\star * *$ & $\star * *$ \\
\hline
\end{tabular}

Mean across tillage systems. May 1993 0-6 inch soil $\mathrm{pH}=5.6$.

Effect of Aglime Rate on Corn Yield, ISU Northwest Research Farm

\begin{tabular}{|c|c|c|c|c|c|c|}
\hline \multirow[b]{2}{*}{ Aglime } & \multicolumn{5}{|c|}{ Year } & \multirow[b]{2}{*}{ Mean } \\
\hline & 1994 & 1995 & 1996 & 1997 & 1998 & \\
\hline Ib ECCE/acre & \multicolumn{6}{|c|}{ 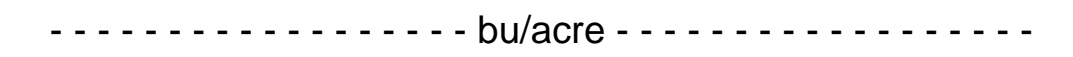 } \\
\hline 0 & 171 & 144 & 122 & 153 & 152 & 149 \\
\hline 500 & 168 & 146 & 126 & 150 & 149 & 148 \\
\hline 1000 & 170 & 145 & 130 & 149 & 152 & 149 \\
\hline 2000 & 170 & 144 & 130 & 148 & 154 & 149 \\
\hline 4000 & 171 & 144 & 127 & 147 & 156 & 149 \\
\hline 6000 & 166 & 146 & 127 & 149 & 154 & 148 \\
\hline Significance & NS & NS & NS & NS & NS & NS \\
\hline
\end{tabular}

Mean across tillage systems. May 1993 0-6 inch soil $\mathrm{pH}=5.6$. 
Table 2. Effect of soil pH on yield of soybeans at several sites in Iowa.

\begin{tabular}{cccccc}
\hline \multicolumn{2}{c}{ Southern Iowa } & \multicolumn{2}{c}{$\begin{array}{c}c \\
\text { Shelby - Grundy }\end{array}$} & \multicolumn{2}{c}{ Moody } \\
\multicolumn{2}{c}{$1966-1972$} & \multicolumn{2}{c}{$1967-1975$} & S675 \\
\hline Soil pH & bu/acre & Soil pH & bu/acre & Soil pH & bu/acre \\
5.3 & 30 & 6.0 & 39 & 6.0 & 31 \\
6.2 & 32 & 6.4 & 38 & 6.1 & 31 \\
7.1 & 34 & 7.1 & 38 & 6.3 & 33 \\
7.5 & 33 & 7.4 & 40 & 6.6 & 33 \\
& & & & 7.0 & 33 \\
\hline
\end{tabular}

Lime for Iowa Soils and Crops, Pm-812, December 1977 (out of print).

Table 3. Effect of soil pH and lime rate on yield of continuous corn at several sites in Iowa.

\begin{tabular}{ccccccc}
\hline $\begin{array}{c}\text { Soil Type: } \\
\text { Soil pH: }\end{array}$ & Fayette & Floyd & Readlyn & Taintor & Nicollet & Galva \\
\hline lb ECCE/acre & 5.6 & 5.7 & 5.9 & 6.0 & 6.1 & 6.1 \\
\hline 0 & 105 & 117 & 153 & 121 & 127 & 122 \\
1,000 & 106 & 121 & 149 & 116 & 123 & 123 \\
2,000 & 105 & 123 & 147 & 122 & 128 & 122 \\
4,000 & 110 & 125 & 154 & 118 & 127 & 122 \\
8,000 & 112 & 126 & 151 & 123 & 129 & 125 \\
16,000 & 112 & 120 & 152 & 121 & 124 & 123 \\
24,000 & 117 & 128 & 154 & 118 & 125 & 123 \\
32,000 & 113 & 126 & 149 & 121 & 125 & 123 \\
\hline
\end{tabular}

Lime for Iowa Soils and Crops, Pm-812, December 1977 (out of print).

Table 4. Effect of surface lime application to no-till corn and soybean grown on a Marshall soil, Iowa State University Armstrong Research Farm, 1999. Initial soil pH was 5.7, with lime surface applied in the spring of 1996. Data from C. Olsen.

\begin{tabular}{|c|c|c|c|c|}
\hline Lime & 1996 & 1997 & 1998 & 1999 \\
\hline Treatment & Soybean & Corn & Soybean & Corn \\
\hline lb ECCE/acre & \multicolumn{4}{|c|}{ 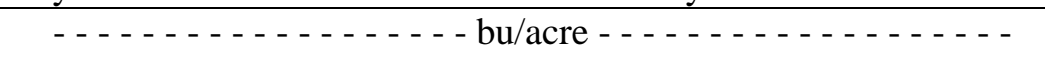 } \\
\hline Check & 52 & 136 & 48 & 148 \\
\hline 250 pelleted lime & 53 & 142 & 50 & 148 \\
\hline 500 pelleted lime & 54 & 144 & 50 & 162 \\
\hline 500 ag lime & 52 & 137 & 49 & 161 \\
\hline 1000 ag lime & 51 & 141 & 50 & 159 \\
\hline 2000 ag lime & 53 & 139 & 48 & 161 \\
\hline 4000 ag lime & 53 & 142 & 49 & 162 \\
\hline 6000 ag lime & 50 & 146 & 50 & 163 \\
\hline Significance & NS & NS & NS & $*$ \\
\hline
\end{tabular}

* Limestone rates of $500 \mathrm{lb}$ ECCE/acre or greater produced significantly higher yield than $250 \mathrm{lb}$ ECCE/acre or no lime. 
Table 5. Effect of lime rate on corn and soybean yield on fields in Plymouth and Crawford counties. Initial soil $\mathrm{pH}$ was approximately 5.3 at the Plymouth site and 5.5 at the Crawford site. Lime applied in spring. Data from R.D. Voss.

\begin{tabular}{lccccc}
\hline \multirow{2}{*}{ Time } & \multicolumn{2}{c}{ Plymouth County } & \multicolumn{2}{c}{ Crawford County } \\
\cline { 2 - 5 } Treatment & 1989 Soybean & 1990 Corn & 1991 Corn & 1990 Soybean & 1991 Corn \\
\hline None & - & 94 & 158 & 43 & 153 \\
250 Pelleted & 33 & 100 & 150 & 48 & 153 \\
500 Pelleted & 33 & 108 & 170 & 47 & 164 \\
250 Fluid & 33 & 104 & 157 & 50 & 159 \\
500 Fluid & 33 & 98 & 158 & 50 & 153 \\
500 Aglime & 31 & 97 & 161 & 50 & 154 \\
1000 Aglime & 29 & 105 & 152 & 48 & 160 \\
2000 Aglime & 33 & 106 & 156 & 49 & 158 \\
4000 Aglime & 35 & 99 & 165 & 49 & 162 \\
6000 Aglime & 32 & 106 & 161 & 47 & 162 \\
Significance & 35 & NS & NS & NS & NS \\
\hline
\end{tabular}

Table 6. Effect of a one-time lime application on corn and soybean yield, 22-year mean yield from 1966 to 1989, Iowa State University Moody experiment farm. Initial soil $\mathrm{pH}$ on zero lime rate $=$ 5.9. Data from A.P. Mallarino.

\begin{tabular}{ccccc}
\hline Lime Rate & Corn & Soybean & 1967 & $1985-86$ \\
\hline ton Lime $^{\mathrm{a}}$ /acre & bu/acre & bu/acre & Soil pH & Soil pH \\
0 & 110 & 39 & 6.0 & 5.9 \\
0.8 & 110 & 40 & 6.1 & 6.1 \\
1.6 & 111 & 41 & 6.3 & 6.2 \\
3.2 & 114 & 41 & 6.6 & 6.3 \\
6.4 & 115 & 42 & 6.9 & 6.5 \\
12.8 & 112 & 42 & 7.1 & 6.9 \\
\hline
\end{tabular}

a $1260 \mathrm{lb} \mathrm{CaCO}_{3} /$ ton.

Table 7. Effect of a one-time lime application on continuous corn yield, 21-year mean yield from 1967 to 1987, Iowa State University Galva-Primghar experiment farm. Initial soil $\mathrm{pH}$ on zero lime rate $=5.9$. Data from A.P. Mallarino.

\begin{tabular}{cccc}
\hline Lime Rate & Corn & 1971 & 1983 \\
\hline ton lime/acre & bu/acre & Soil pH & Soil pH \\
0 & 129 & 5.9 & 5.7 \\
0.5 & 128 & 5.9 & 5.6 \\
1.0 & 128 & 6.2 & 5.8 \\
2.0 & 131 & 6.4 & 6.1 \\
4.0 & 130 & 6.8 & 6.2 \\
8.0 & 132 & 7.3 & 6.8 \\
12.0 & 131 & 7.5 & 7.3 \\
16.0 & 132 & 7.7 & 7.6 \\
\hline
\end{tabular}


Table 8. Effect of annual lime application rate on corn yields, Clarion-Webster research center and Galva research farm, 24-year mean yield from 1963 to 1986. Soil pH in $1963=5.8$ to 5.9. Data from A.P. Mallarino.

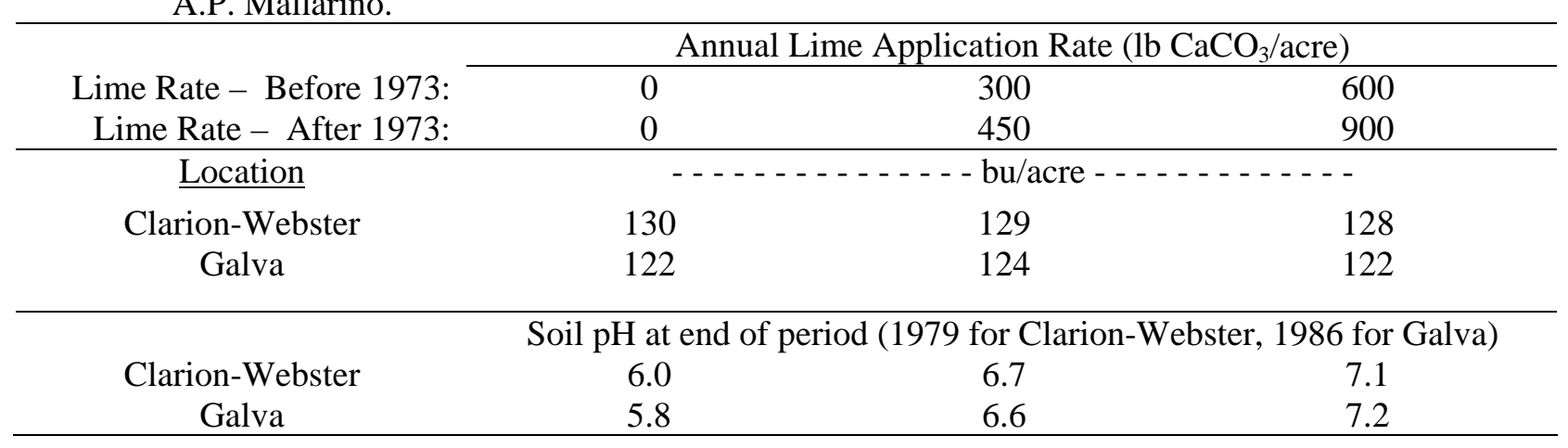

Table 9. Influence of previous forage legume on subsequent corn N needs.

\begin{tabular}{lccc}
\hline State & $\begin{array}{c}\text { Site } \\
\text { Years }\end{array}$ & $\begin{array}{c}\text { Responsive } \\
\text { Sites }\end{array}$ & $\begin{array}{c}\text { Optimum } \\
\text { N Rate }\end{array}$ \\
\hline Iowa (Voss and Shrader, 1981) & & & lb/acre \\
Iowa (Morris et al., 1993) & 11 & 0 & 0 \\
Wisconsin (Bundy and Andraski, 1993) & 29 & 6 & 25 \\
Minnesota (Schmitt and Randall, 1994) & 5 & 0 & 0 \\
Illinois (Brown and Hoeft, 1997) & 4 & 1 & 42 \\
Pennsylvania (Fox and Piekielek, 1998) & 2 & 0 & 0 \\
\hline
\end{tabular}

Table 10. Yield benefits of soybean-corn rotation compared to continuous corn in selected experiments (from Bundy, 1998).

\begin{tabular}{|c|c|c|}
\hline Location & Yield Benefit $^{1}$ & Reference \\
\hline & $----\%---$ & \\
\hline Illinois & 16 & Welch (1976) \\
\hline Iowa & 11 & Meese (1993) \\
\hline Minnesota & 10 & Crookston et al. (1991) \\
\hline Minnesota & 33 & Hesterman et al. (1986) \\
\hline Nebraska & 27 & Kessavalou \& Walters (1997) \\
\hline Wisconsin & 10 & Lund et al. (1993) \\
\hline Wisconsin & 15 & Meese et al. (1991) \\
\hline
\end{tabular}


Table 11. Apparent nitrogen contributions from soybean to a subsequent corn crop (from Bundy, 1998).

\begin{tabular}{|c|c|c|c|c|}
\hline Location & \multicolumn{3}{|c|}{ Apparent $\mathrm{N}$ contribution } & \multirow[t]{3}{*}{ Reference } \\
\hline & FRV $^{1}$ & $\mathrm{DNM}^{2}$ & Avg. $^{3}$ & \\
\hline & \multicolumn{3}{|c|}{ - - - - - - - - - - - lb N/acre - - - - - - - - - - - } & \\
\hline Iowa & -- & -219 to 204 & 60 & Blackmer (1996), Meese (1993) \\
\hline Missouri & -- & 0 to 142 & 48 & Stecker et al. (1995) \\
\hline Quebec & 36 to 134 & -- & 90 & Rembon \& MacKenzie (1997) \\
\hline Wisconsin & 0 to 83 & -20 to 188 & 47 & Bundy et al. (1993) \\
\hline
\end{tabular}

Table12. Effect of crop rotation on corn yield and N need, Northeast Research and Demonstration Farm, 1979 - 1998, A.P. Mallarino and K. Pecinovsky, 1998.

\begin{tabular}{lcccc}
\hline & \multicolumn{4}{c}{ N rate applied to corn, lb N/acre } \\
\cline { 2 - 5 } Crop/Rotation & 0 & 80 & 160 & 240 \\
\hline & 55 & 106 & 128 & 135 \\
\hline \hline Corn & 100 & 141 & 148 & 151 \\
Soybean & 43 & 45 & 44 & 44 \\
\hline \hline Corn & 101 & 137 & 148 & 150 \\
Corn & 56 & 106 & 129 & 135 \\
Soybean & 47 & 46 & 47 & 47 \\
\hline \hline Corn & 100 & 135 & 147 & 147 \\
Corn & 58 & 108 & 131 & 136 \\
Corn & 57 & 103 & 127 & 134 \\
Soybean & 49 & 48 & 48 & 48 \\
\hline \hline Soybean & 36 & 37 & 39 & 38 \\
\hline
\end{tabular}

Table 13. Effect of crop rotation on corn yield and N need, Northern Research and Demonstration Farm, 1985-1998, A.P. Mallarino and D. Rueber, 1998.

\begin{tabular}{|c|c|c|c|c|}
\hline \multirow[b]{2}{*}{ Crop/Rotation } & \multicolumn{4}{|c|}{$\mathrm{N}$ rate applied to corn. lb N/acre } \\
\hline & 0 & 80 & 160 & 240 \\
\hline & \multicolumn{4}{|c|}{ - - - - - - - - bu/acre - - - - - - - - } \\
\hline Corn, spring urea & 53 & 108 & 134 & 146 \\
\hline $\begin{array}{l}\text { Corn, fall urea } \\
\end{array}$ & 50 & 93 & 124 & 134 \\
\hline$\overline{\text { Corn, spring urea }}$ & 100 & 139 & 157 & 162 \\
\hline Soybean & 42 & 43 & 43 & 42 \\
\hline
\end{tabular}


Table 14. Effect of season on plateau $\mathrm{N}$ rate and corn yield, University of Illinois Northwestern Illinois Agricultural Research and Demonstration Center, Monmouth, Illinois.

\begin{tabular}{|c|c|c|c|c|c|}
\hline \multicolumn{3}{|c|}{ Higher Yielding Years } & \multicolumn{3}{|c|}{ Lower Yielding Years } \\
\hline Year & Plateau Yield & Plateau N Rate & Year & Plateau Yield & Plateau N Rate \\
\hline & bu/acre & lb N/acre & & bu/acre & lb N/acre \\
\hline 1984 & 198 & 117 & 1988 & 100 & 50 \\
\hline 1985 & 190 & 123 & 1989 & 115 & 7 \\
\hline 1987 & 191 & 97 & 1991 & 152 & 59 \\
\hline 1994 & 225 & 157 & 1992 & 164 & 108 \\
\hline 1996 & 203 & 92 & 1993 & 160 & 161 \\
\hline & & & 1995 & 153 & 205 \\
\hline
\end{tabular}

1983 - 1996, Corn - Soybean Rotation

1983 - 1996, Average 171 bu/acre

Table 15. Influence of swine manure application on corn yield, Northern Research and Demonstration Farm, R. Killorn, 1998. Manure applied to supply approximately $150 \mathrm{lb}$ total N/acre. Site had high soil test $\mathrm{P}$ and $\mathrm{K}$.

\begin{tabular}{|c|c|c|c|}
\hline $\begin{array}{c}\text { Manure Frequency } \\
\text { in Rotation }\end{array}$ & 1994 & 1996 & 1998 \\
\hline & \multicolumn{3}{|c|}{ - - - - - - bu/acre - - . - - } \\
\hline Every Year & 191 & 163 & 232 \\
\hline Every Other Year to Corn & 198 & 149 & 195 \\
\hline Every $4^{\text {th }}$ Year to Corn & 191 & 100 & 199 \\
\hline No Manure (Fertilizer): 0 & 170 & 96 & 121 \\
\hline 100 & 186 & 135 & 177 \\
\hline 150 & 186 & 130 & 178 \\
\hline
\end{tabular}

Table 16. Mean yields of corn as affected by $\mathrm{N}$ fertilization rate on 148 Iowa manured fields having various concentrations of nitrate before fertilization, Hansen et al., 1998.

\begin{tabular}{ccccc}
\hline Soil Nitrate & \multicolumn{4}{c}{ Mean yield of grain } \\
\cline { 2 - 5 } Concentration & 0 lb N/acre & 30 lb N/acre & 60 lb N/acre & 90 lb N/acre \\
\hline ppm-N & $-\cdots-13$ & 126 & 130 & 134 \\
$<11(115)^{\dagger}$ & 114 & 138 & 145 & 145 \\
11 to $15(160)$ & 132 & 153 & 153 & 153 \\
16 to $20(104)$ & 148 & 159 & 159 & 159 \\
$>20(202)$ & 157 &
\end{tabular}

${ }^{\dagger}$ Numbers in parentheses indicate the number of blocks (four blocks per trial) testing in each category. 
Table 17. Average V4 soil nitrate $\mathrm{N}$ concentration and corn grain yields from selected manure and fertilizer $\mathrm{N}$ treatments at seven sites in Minnesota. Randall et al., J. Prod. Agric. 2:317-323 (1999).

\begin{tabular}{lcccccc}
\hline & \multicolumn{3}{c}{ Dairy } & \multicolumn{3}{c}{ Swine } \\
\cline { 2 - 6 } Treatment & Nitrate N & Yield & Rel. Yield & Nitrate N & Yield & Rel. Yield \\
\hline & ppm & bu/acre & $\%$ & ppm & bu/acre & $\%$ \\
Control (0 lb N/acre) & 4.5 & 110 & 70 & 6.4 & 109 & 68 \\
October Manure & 9.2 & 147 & 94 & 14.9 & 155 & 96 \\
April manure & 12.7 & 151 & 97 & 26.0 & 174 & 108 \\
150 lb N/acre & 26.8 & 156 & 100 & 27.0 & 162 & 100 \\
\hline
\end{tabular}

Dairy manure applied at 8000 gal/acre and swine manure applied at 3000 or 4000 gal/acre to supply approximate optimum amount of $\mathrm{N}$.

Table 18. Corn yield, soybean yield, and soil test $\mathrm{P}$ as affected by initial and annual $\mathrm{P}$ fertilizer application, Kanawha, IA (Clarion-Webster Research Center).

\begin{tabular}{|c|c|c|c|c|c|c|c|c|c|c|c|c|c|c|}
\hline \multirow{2}{*}{$\begin{array}{l}\text { Application }^{\mathrm{b}} \\
1975 \text { Annual }\end{array}$} & \multicolumn{14}{|c|}{ Year } \\
\hline & 1976 & 1977 & 1978 & 1979 & 1980 & 1981 & 1982 & 1983 & 1984 & 1985 & 1986 & 1987 & 1988 & 1989 \\
\hline \multicolumn{15}{|c|}{$\begin{array}{c}\text { - Corn or Soybean, bu/acre } \\
\text { Corn }\end{array}$} \\
\hline 0 & 138 & 134 & 151 & 161 & 158 & 163 & 146 & 120 & 111 & 145 & 116 & 130 & 60 & 123 \\
\hline 23 & 140 & 135 & 153 & $166^{\mathrm{a}}$ & $167^{\mathrm{a}}$ & $179^{\mathrm{a}}$ & $168^{\mathrm{a}}$ & $152^{\mathrm{a}}$ & $140^{\mathrm{a}}$ & $175^{\mathrm{a}}$ & $154^{\mathrm{a}}$ & $161^{\mathrm{a}}$ & $90^{\mathrm{a}}$ & $161^{\mathrm{a}}$ \\
\hline & \multicolumn{14}{|c|}{ Soybean } \\
\hline 0 & 39 & 35 & 44 & 41 & 39 & 38 & 38 & 36 & 32 & 25 & 33 & 32 & 28 & 28 \\
\hline 23 & 40 & 36 & 43 & $42^{\mathrm{a}}$ & $42^{\mathrm{a}}$ & $40^{\mathrm{a}}$ & $43^{\mathrm{a}}$ & $44^{\mathrm{a}}$ & $41^{\mathrm{a}}$ & $31^{\mathrm{a}}$ & $41^{\mathrm{a}}$ & $38^{\mathrm{a}}$ & $36^{\mathrm{a}}$ & $30^{\mathrm{a}}$ \\
\hline Soil P, $\mathrm{ppm}^{\mathrm{c}}$ : & 14 & 13 & 11 & 9 & 9 & 9 & 8 & 6 & 6 & 7 & 7 & 6 & 6 & 3 \\
\hline \multirow[t]{4}{*}{300} & \multicolumn{14}{|c|}{ Corn } \\
\hline & 139 & 135 & 157 & 177 & 170 & 185 & 179 & 147 & 152 & 175 & 157 & 153 & 75 & 143 \\
\hline & 145 & 136 & 155 & 172 & 171 & 187 & 185 & 153 & 153 & $180^{\mathrm{a}}$ & 162 & $168^{\mathrm{a}}$ & $93^{\mathrm{a}}$ & $157^{\mathrm{a}}$ \\
\hline & \multicolumn{14}{|c|}{ Soybean } \\
\hline 0 & 40 & 37 & 43 & 44 & 44 & 41 & 41 & 44 & 38 & 29 & 36 & 42 & 33 & 33 \\
\hline 23 & 41 & 37 & 46 & 44 & 43 & 43 & 44 & 45 & 39 & 32 & $43^{\mathrm{a}}$ & 47 & $37^{\mathrm{a}}$ & $38^{\mathrm{a}}$ \\
\hline Soil P, $\mathrm{ppm}^{\mathrm{c}}$ : & 33 & 36 & 29 & 23 & 25 & 23 & 18 & 14 & 13 & 14 & 15 & 10 & 9 & 8 \\
\hline 600 & \multicolumn{14}{|c|}{ Corn } \\
\hline 0 & 125 & 133 & 153 & 172 & 170 & 178 & 182 & 158 & 155 & 187 & 160 & 165 & 97 & 166 \\
\hline 23 & 129 & 136 & 148 & 174 & 168 & 182 & 182 & 154 & 156 & 182 & 159 & 166 & 90 & 175 \\
\hline & \multicolumn{14}{|c|}{ Soybean } \\
\hline 0 & 39 & 35 & 44 & 44 & 40 & 43 & 41 & 43 & 38 & 31 & 40 & 43 & 38 & 30 \\
\hline 23 & 37 & 36 & 44 & 43 & 40 & 41 & 43 & 41 & 40 & 31 & 41 & 45 & 35 & 32 \\
\hline Soil P, ppm': & 68 & 60 & 43 & 43 & 42 & 37 & 32 & 23 & 26 & 22 & 22 & 19 & 18 & 12 \\
\hline
\end{tabular}

a Significant yield increase to annual $\mathrm{P}$ application.

b Initial 1975 application a one-time application of 0 , 300, or $600 \mathrm{lb}_{2} \mathrm{O}_{5}$ /acre in the spring of 1975. Initial soil test of 17 ppm with zero P applied.

c Bray $\mathrm{P}_{1}$ soil test of the zero annual $\mathrm{P}$ application treatment.

Data from Webb et al., J. Prod. Agric. 5:148-152 (1992). 
Table 19. Corn yield, soybean yield, and soil test $\mathrm{K}$ as affected by initial and annual $\mathrm{K}$ fertilizer application, Kanawha, IA (Clarion-Webster Research Center).

\begin{tabular}{|c|c|c|c|c|c|c|c|c|c|c|c|c|c|c|}
\hline Application & \multicolumn{7}{|c|}{ Corn } & \multicolumn{7}{|c|}{ Soybean } \\
\hline Initial $^{\mathrm{d}}$ Annual & 1976 & 1978 & 1980 & 1982 & 1984 & 1986 & 1988 & 1977 & 1979 & 1981 & 1983 & 1985 & 1987 & 1989 \\
\hline lb K ${ }_{2} \mathrm{O} /$ acre & & - - - & - & -1 & $-\ldots$ & $-\ldots$ & - - - bu & cre - & $\ldots$ & $-\ldots$ & $-\ldots$ & $-\ldots$ & $-\ldots$ & - \\
\hline 0 & 121 & 134 & 146 & 162 & 122 & 161 & 100 & 32 & 34 & 32 & 38 & 15 & 35 & 26 \\
\hline Avg. ${ }^{c}$ & $131^{\mathrm{a}}$ & $147^{\mathrm{a}}$ & $159^{a}$ & $180^{\mathrm{a}}$ & $155^{\mathrm{a}}$ & $171^{\mathrm{a}}$ & $120^{a}$ & $34^{\mathrm{a}}$ & $38^{\mathrm{a}}$ & $36^{\mathrm{a}}$ & $45^{\mathrm{a}}$ & $24^{\mathrm{a}}$ & $43^{a}$ & $29^{\mathrm{a}}$ \\
\hline Soil K, ppm ${ }^{\mathrm{b}}$ & 54 & 58 & 53 & 50 & 53 & 51 & -- & 65 & 54 & 66 & 45 & 58 & 49 & 56 \\
\hline 600 & 136 & 153 & 156 & 182 & 147 & 161 & 125 & 36 & 38 & 35 & 44 & 16 & 41 & 30 \\
\hline Avg. ${ }^{c}$ & 135 & 150 & 162 & 183 & $158^{\mathrm{a}}$ & $171^{\mathrm{a}}$ & 119 & 35 & $40^{\mathrm{a}}$ & 38 & 46 & $24^{\mathrm{a}}$ & $44^{\mathrm{a}}$ & 29 \\
\hline Soil K, ppm ${ }^{\mathrm{b}}$ & 88 & 86 & 62 & 64 & 58 & 52 & -- & 103 & 70 & 91 & 54 & 68 & 58 & 64 \\
\hline 1400 & 131 & 151 & 172 & 182 & 158 & 174 & 114 & 34 & 42 & 40 & 47 & 23 & 43 & 27 \\
\hline Avg. ${ }^{c}$ & 131 & 152 & 171 & 185 & 159 & 171 & 113 & 34 & 41 & 37 & 46 & 25 & $46^{\mathrm{a}}$ & $31^{\mathrm{a}}$ \\
\hline Soil K, ppm ${ }^{\mathrm{b}}$ & 182 & 133 & 103 & 89 & 76 & 69 & -- & 189 & 121 & 130 & 81 & 87 & 80 & 74 \\
\hline
\end{tabular}

a Significant yield increase to the average annual K applications.

${ }^{\mathrm{b}}$ Ammonium acetate dry soil sample $\mathrm{K}$ test of the zero annual $\mathrm{K}$ rate application treatment.

c Average yield for all of the annual $\mathrm{K}$ fertilized treatments.

${ }^{\mathrm{d}}$ Initial K application totals were annual application of 60 or $240 \mathrm{lb} \mathrm{K} \mathrm{K}_{2} \mathrm{O} / \mathrm{acre}$ from 1971 to 1974 to corn, and one application of 360 or $480 \mathrm{lb} \mathrm{K}_{2} \mathrm{O} /$ acre to soybean in the spring of 1975 . Initial soil test of $56 \mathrm{ppm}$ with zero K applied.

Data from Mallarino et al., J. Prod. Agic. 4:560-566 (1991).

Table 20. Change in soil test $\mathrm{P}$ from withholding annual $\mathrm{P}$ fertilizer application at three different initial soil test P levels, Kanawha, IA (Clarion-Webster Research Center).

\begin{tabular}{|c|c|c|c|c|c|}
\hline $\begin{array}{c}\text { Initial P } \\
\text { Application }^{\mathrm{a}}\end{array}$ & Time Period & $\begin{array}{c}\text { Starting Fall } \\
\text { Soil Test P }\end{array}$ & $\begin{array}{c}\text { Soil Test After } \\
4 \text { Crop Years }\end{array}$ & $\begin{array}{c}\text { Change in Soil } \\
\text { Test }\end{array}$ & $\begin{array}{l}\text { Change in Soil } \\
\text { Test per Year } \\
\text { Over 4-Year } \\
\text { Period }\end{array}$ \\
\hline lb $\mathrm{P}_{2} \mathrm{O}_{5} /$ acre & & \multicolumn{4}{|c|}{ 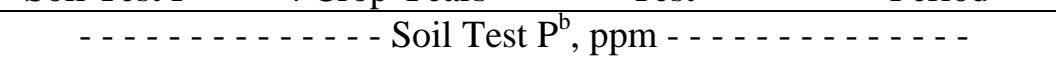 } \\
\hline 0 & $\begin{array}{l}1976-1979 \\
1980-1983 \\
1984-1987\end{array}$ & $\begin{array}{c}17 \\
9 \\
6\end{array}$ & $\begin{array}{l}9 \\
6 \\
6\end{array}$ & $\begin{array}{c}-8 \\
-3 \\
0\end{array}$ & $\begin{array}{c}-2.0 \\
-0.75 \\
0\end{array}$ \\
\hline 300 & $\begin{array}{l}1976-1979 \\
1980-1983 \\
1984-1987\end{array}$ & $\begin{array}{l}43 \\
23 \\
14\end{array}$ & $\begin{array}{l}23 \\
14 \\
10\end{array}$ & $\begin{array}{l}-20 \\
-9 \\
-4\end{array}$ & $\begin{array}{l}-5.0 \\
-2.25 \\
-1.0\end{array}$ \\
\hline 600 & $\begin{array}{l}1976-1979 \\
1980-1983 \\
1984-1987\end{array}$ & $\begin{array}{l}75 \\
43 \\
23\end{array}$ & $\begin{array}{l}43 \\
23 \\
19\end{array}$ & $\begin{array}{l}-32 \\
-20 \\
-4\end{array}$ & $\begin{array}{l}-8.0 \\
-5.0 \\
-1.0\end{array}$ \\
\hline
\end{tabular}

\footnotetext{
${ }^{\mathrm{a}}$ Initial P application a one-time application of 0, 300, or $600 \mathrm{lb}_{2} \mathrm{O}_{5} /$ acre in the spring of 1975.
}

${ }^{\mathrm{b}}$ Bray $\mathrm{P}_{1}$ soil test of the zero annual $\mathrm{P}$ application treatment.

Data calculated from Webb et al., J. Prod. Agric. 5:148-152 (1992). 
Table 21. Change in soil test $\mathrm{K}$ from withholding annual $\mathrm{K}$ fertilizer application at three different initial soil test K levels, Kanawha, IA (Clarion-Webster Research Center).

\begin{tabular}{|c|c|c|c|c|c|}
\hline $\begin{array}{c}\text { Initial K } \\
\text { Application }^{\mathrm{a}}\end{array}$ & Time Period & $\begin{array}{l}\text { Starting fall } \\
\text { Soil Test K }\end{array}$ & $\begin{array}{c}\text { Soil Test After } \\
4 \text { Crop Years }\end{array}$ & $\begin{array}{c}\text { Change in Soil } \\
\text { Test }\end{array}$ & $\begin{array}{l}\text { Change in Soil } \\
\text { Test per Year } \\
\text { Over 4-Year } \\
\text { Period } \\
\end{array}$ \\
\hline lb $\mathrm{K}_{2} \mathrm{O} /$ acre & & \multicolumn{4}{|c|}{ - - - - - - - - - Soil Test Kb, ppm - - - - - - - - } \\
\hline 0 & $\begin{array}{l}1976-1979 \\
1980-1983 \\
1984-1987\end{array}$ & $\begin{array}{l}56 \\
54 \\
45\end{array}$ & $\begin{array}{l}54 \\
45 \\
49\end{array}$ & $\begin{array}{l}-2 \\
-9 \\
+4\end{array}$ & $\begin{array}{l}-0.5 \\
-2.25 \\
+1.0\end{array}$ \\
\hline 600 & $\begin{array}{l}1976-1979 \\
1980-1983 \\
1984-1987\end{array}$ & $\begin{array}{c}127 \\
70 \\
54\end{array}$ & $\begin{array}{l}70 \\
54 \\
58\end{array}$ & $\begin{array}{l}-57 \\
-16 \\
+4\end{array}$ & $\begin{array}{l}-14.0 \\
-4.0 \\
+1.0\end{array}$ \\
\hline 1400 & $\begin{array}{l}1976-1979 \\
1980-1983 \\
1984-1987\end{array}$ & $\begin{array}{c}298 \\
121 \\
81 \\
\end{array}$ & $\begin{array}{c}121 \\
81 \\
80 \\
\end{array}$ & $\begin{array}{c}-177 \\
-40 \\
-1 \\
\end{array}$ & $\begin{array}{l}-44.0 \\
-10.0 \\
-0.25 \\
\end{array}$ \\
\hline
\end{tabular}

${ }^{\mathrm{a}}$ Initial K application a one-time application of 0 , 600, or $1400 \mathrm{lb} \mathrm{K}_{2} \mathrm{O} /$ acre in the spring of 1975.

${ }^{\mathrm{b}}$ Ammonium acetate dry $\mathrm{K}$ soil test of the zero annual $\mathrm{K}$ application treatment.

Data calculated from Mallarino et al., J. Prod. Agric. 4:560-566 (1991).

Table 22. Change in soil test $\mathrm{K}$ from withholding annual $\mathrm{K}$ fertilizer application at four different initial soil test K levels, Boone, IA (Agronomy \& Agricultural Engineering Research Center).

\begin{tabular}{cccccc}
\hline $\begin{array}{c}\text { Initial K } \\
\text { Application }\end{array}$ & Time Period & $\begin{array}{c}\text { Starting Fall } \\
\text { Soil Test K }\end{array}$ & $\begin{array}{c}\text { Soil Test After } \\
\text { 4 Crop Years }\end{array}$ & $\begin{array}{c}\text { Change in Soil } \\
\text { Test }\end{array}$ & $\begin{array}{c}\text { Change in Soil } \\
\text { Test per Year } \\
\text { Over 4-Year } \\
\text { Period }\end{array}$ \\
\hline $\begin{array}{c}\text { lb K }_{2} \text { O/acre } \\
0\end{array}$ & & ---18 & -18 & -4.5 \\
& $1976-1979$ & 71 & 53 & +2 & +0.5 \\
& $1980-1983$ & 53 & 55 & +1 & +0.25 \\
300 & $1984-1987$ & 55 & 56 & -65 & -16.0 \\
& $1976-1979$ & 128 & 63 & -5 & -1.25 \\
& $1980-1983$ & 63 & 58 & +10 & +2.5 \\
600 & $1984-1987$ & 58 & 68 & -166 & -42.0 \\
& $1976-1979$ & 257 & 91 & -15 & -3.75 \\
& $1980-1983$ & 91 & 76 & -6 & -1.5 \\
& $1984-1987$ & 76 & 70 & -184 & -46.0 \\
& $1976-1979$ & 318 & 134 & -38 & -9.5 \\
& $1980-1983$ & 134 & 96 & -6 & -1.5 \\
\hline
\end{tabular}

${ }^{\mathrm{a}}$ Initial K application totals were annual application of 0, 50, 100, or $200 \mathrm{lb} \mathrm{K}$ O/acre in 1973 and 1974, and one application of 0, 200, 400, or $600 \mathrm{lb} \mathrm{K}_{2} \mathrm{O} /$ acre in the spring of 1975.

${ }^{\mathrm{b}}$ Ammonium acetate dry $\mathrm{K}$ soil test of the zero annual $\mathrm{K}$ application treatment.

Data calculated from Mallarino et al., J. Prod. Agric. 4:560-566 (1991). 